\title{
Effect of heat on Organic and Inorganic components in some Non-coking Lower Gondwana Coals
}

\section{Rajesh Bhatta}

Council of Scientific and Industrial Research Institute of Minerals and Materials Technology

Nilima Dash ( $\nabla$ nilima@immt.res.in )

Institute of Minerals and Materials Technology CSIR https://orcid.org/0000-0002-9815-7940

Bibhuranjan Nayak

Council of Scientific and Industrial Research Institute of Minerals and Materials Technology

\section{Research}

Keywords: Heat treatment, Micropetrography, Heavy media separation, Lower Gondwana coal

Posted Date: August 26th, 2020

DOI: https://doi.org/10.21203/rs.3.rs-62913/v1

License: (c) (i) This work is licensed under a Creative Commons Attribution 4.0 International License.

Read Full License

Version of Record: A version of this preprint was published at Transactions of the Indian Institute of Metals on January 5th, 2021. See the published version at https://doi.org/10.1007/s12666-020-02168-4. 


\title{
Effect of heat on Organic and Inorganic components in some Non-coking Lower Gondwana Coals
}

\author{
Rajesh Bhatta ${ }^{1,2}$, Nilima Dash ${ }^{1,2 *}$, Bibhuranjan Nayak ${ }^{2}$ \\ ${ }^{1}$ Academy of Scientific and Innovative Research (AcSIR), Ghaziabad-201002, India \\ ${ }^{2}$ CSIR-Institute of Minerals and Materials Technology, Bhubaneswar-751013, India
}

(*E-mail: nilima@immt.res.in)

\begin{abstract}
The concentration of different maceral groups and minerals in coal influence the quality as each of them behaves differently during heat treatment. The purpose of this study is to know how the maceral groups and minerals are behaving at different temperature conditions. Therefore, various maceral groups and minerals were concentrated by using heavy liquids of different specific gravities $(1.3,1.7$ and 1.9). The generated density fractions were treated with heat at $400,600,800$ and $1000^{\circ} \mathrm{C}$. All the density fractions at various temperature conditions along with feed sample were investigated by Optical Microscopy, X-ray Diffractometry (XRD), Electron-probe Micro Analysis (EPMA) and Fourier Transform Infrared Spectroscopy (FTIR) analysis. The results from these analyses suggest that fusinite and sclerotinite are the most stable macerals, whereas quartz is the most stable mineral during pyrolysis. Telocollinite found to be oxidized very prominently at $400^{\circ} \mathrm{C}$. Siderite and pyrite thermally altered to form hematite above $400^{\circ} \mathrm{C}$ and $800^{\circ} \mathrm{C}$ respectively. Kaolinite converted to metakaolin followed by mullite with increasing temperature.
\end{abstract}

Keywords: Heat treatment, Micropetrography, Heavy media separation, Lower Gondwana coal

\section{Introduction}

Coal has been continuing to be the leading fuel resource for power generation. Use of coal in different sectors largely depends on its heating value. Although different factors affect the combustion capacity of the coal, the distribution of organic and inorganic components plays a vital role. Coal constitutes mostly of organic matter with a subordinate amount of inorganic matter (Thomas 2013). In this context, it is necessary to know the behaviour of macerals as well as mineral constituents of coal that reacts differently towards heat (Querol, Turiel and Soler 1994; Vassileva and Vassilev 2006; Dyk et al. 2009). Generally, inertinites are less reactive than vitrinite and liptinite due to its aromatic nature and their presence in variable amount directly affect the coking properties of a particular coal (Nag, Das and Saxena 2016). Macerals like fusinite, sclerotinite and semifusinite of inertinite group show maximum stability among the macerals during combustion (White, Davies and Jones 1989; Xie et al. 1991; Blanc et al. 1991; Sun, Chen and Li. 2003; Morga 2010). However, some inertinites of lower reflectance are semi-reactive (Kruszewska 1989). The unburnt carbon or char particles in ash are mainly contributed by the inertinite group of macerals (Yavorski et al. 1968). Hence, the combustion efficiency of coal is inversely related to the concentration of inertinite and oxidized vitrinite. The organic components of coal, each have their influence on its caking capacity, particularly when it gets oxidized (Sahoo et al. 2019). Among maceral groups, vitrinite relatively contains more oxygen than others and are more susceptible to oxidation (Nandi, Brown, and Lee 1977). So, it is vitrinite which plays a significant role in spontaneous combustion. 
Besides the macerals, inorganic constituents behave differently (Nankervis and Furlong 1980; Raask 1985; Burchill, Richards and Warrington 1990; Vassilev et al. 1995; Vassileva and Vassilev 2005; Reifenstein et al. 1999; Ozbas and Kok 2003; Acma et al. 2006; Giroux, Charland and MacPhee 2006) depending on their nature of occurrence, whether included or excluded. Minerals either undergo own series of reactions or form a new phase with the interaction of other phases. After combustion or gasification, the primary source of glass is derived from included minerals in carbon-rich particles and slag formation decreases or concentration of crystalline phases increase at a specific temperature. To study the constituents individually, attempts have been made to liberate them from each other by different methods using their density difference (Kinghorn and Rahman 1980; Dyrkacz and Horwitz 1982). The degree of separation of the macerals greatly depends on their association (Holuszko et al. 2018). Literature reports that vitrinite liberates in a more delicate form from high volatile bituminous coal when crushed into -3mm size (Zhang et al. 2016). As the Lower Gondwana bituminous coals are commonly vitriniterich, the same can be collected in more pure form. Since mineralogical as well as structural changes occur in coal during the combustion process, Electron-probe microanalysis has been quite useful which provides necessary information for understanding the physical and chemical transformation of mineral phases (Vassileva and Vassilev 2002; Nayak 2013; Bhowmick, Nayak and Varma 2017). To investigate the structural changes in the organic matters and the sustainability of bonds, the use of Fourier Transform Infrared Spectroscopy (FTIR) has significant advantages for its high sensitivity and data representation capacity (Koenig 1975). Many authors have reported on the suitability of FTIR for the analysis of coal (Solomon and Carangelo 1988; Saikia, Boruah and Gogoi 2007; Cheng et al. 2017; Xuguang 2005; Yao et al. 2011; Balachandran 2014; Orrego, Hernandez and Mej1a-Ospino 2010). The behaviour of Lower Gondwana coals of Talcher coalfield during the combustion process have not well understood yet. Therefore, in the present study, we have tried to find out and understand the effect of heat on macerals and minerals during pyrolysis of a low ash non-coking coal collected from Nandira colliery of Talcher coalfield.

\section{Geological Setting}

The Lower Gondwana-Talcher coalfield of Odisha lies at the south-eastern part of the Mahanadi basin. The study

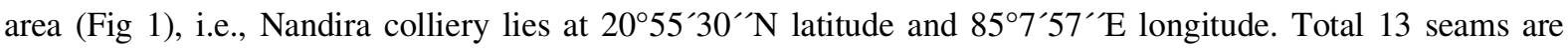
exposed in this coalfield of which seam-I belongs to Karharbari Formation and the rest are Barakar Formation. Only the seam-I is exposed in the study area in association with carbonaceous shale and sandstone.

\section{[Fig 1 near here]}

\section{Materials and Methods}

Coal samples from working faces of different partings of seam-I of Nandira underground colliery of Talcher coalfield were collected and mixed to make a representative sample. The sample contains $7.96 \%$ moisture, $17.24 \%$ ash, $30.43 \% \mathrm{VM}$, and fixed carbon of $44.37 \%$. The feed coal sample was crushed and passed through $3.34 \mathrm{~mm}$ sieve from which $1 \mathrm{~kg}$ of sample was taken by conning and quartering method for different studies. To differentiate between organic and inorganic components present in coal, Heavy Media Separation (HMS) technique was adopted by taking advantage of differential specific gravities of macerals [e.g., liptinite: 1.00- $1.28 \mathrm{gm} / \mathrm{ml}$., vitrinite: $1.30-1.80 \mathrm{gm} / \mathrm{ml}$. and inertinite: $1.35-2.00 \mathrm{gm} / \mathrm{ml}$.]. The minerals associated with coal have a specific 
gravity greater than 2.0. Following this data, three heavy liquids with specific gravity of $1.3,1.7$ and $1.9 \mathrm{gm} / \mathrm{ml}$. were prepared by mixing bromoform and acetone in appropriate proportions. Sink-float tests were conducted by using these three liquids where four numbers of sample fractions were generated as float of 1.3 , sink of 1.3, 1.7 and 1.9 namely F1, S1, S2 and S3.

Further, these four sample fractions were treated with heat at $400^{\circ} \mathrm{C}, 600^{\circ} \mathrm{C}, 800^{\circ} \mathrm{C}$ and $1000^{\circ} \mathrm{C}$ separately for one hour each within a muffle furnace in an oxidizing environment. The product of each fraction was petrographically investigated using a coal petrographic microscope (Leica DM4500P attached with fluorescence light and petroglite counting system) following standard procedure (IS: 9127, 2002). The importance of petrographic study in coal characterization for their quality assessment and optimum utilization has been described by some researchers (Stach et al. 1982; M.P. Singh, P.K. Singh and A.K. Singh 2003; Misra and Mohanty 2005; Singh 2016). Mineralogical phases were identified on the heat-treated samples using an X-ray diffractometer (Philips PW-1710). Electron microprobe (JEOL JXA-8200) analysis was carried out to supplement the mineralogical studies in the heat-affected samples. Further, to identify and delineate the existing bonds, the powder samples of each fraction were taken for Fourier-transform infrared (Spectrum gx) spectroscopic study.

\section{Results and Discussion}

\subsection{Micropetrography}

Quantified petrographic data of different density fractions treated with heat at various temperature conditions have been generated by optical microscopy (Table.1). The heat affected macerals and minerals that altered partially or fully were identified and the oxidized macerals which are mostly vitrinites were marked by the formation of the oxidized rim.

\section{[Table 1 near here]}

The abundance of vitrinite followed by inertinite and liptinite with a significant amount of mineral matter is marked in the feed sample. The maximum concentration of vitrinite in the S1 fraction is agreeing with the availability of vitrinite in the feed sample. Liptinite having least specific gravity was enriched in the F1 fraction. Although mineral matters were found in each of the density fractions due to its syngenetic and interstitial nature, it is mostly concentrated in the highest density fraction S3. Vitrinite is enriched in S1 and inertinite in S2 fraction with respect to their specific gravities. The highest density fraction S3 is almost composed of inorganic constituents with a little amount of macerals. The optical micrographs of feed and the separated fractions treated with various temperatures show remarkable changes in both macerals as well as minerals present in the coal. Telocollinite and corpocollinite were abundant among the vitrinite group of macerals. Figure 2a shows the presence of corpocollinite filled with inclusions of minerals such as clay and iron. Other than vitrinite, cutinite (Fig 2b) and sporinite of liptinite group are also present. Amongst the inertinite group macerals, fusinite (Fig 2c), semifusinite and sclerotinite are mostly observed in the sample. The occurrence of bi- and tri- macerals (Fig 2d) were common.

The oxidized macerals are only observed at $400^{\circ} \mathrm{C}$ of each fraction, and it is mostly telocollinite (Fig 2e) that was found to be oxidized much readily than others. It is well known that vitrinite contains comparatively more oxygen than other macerals and hence plays a significant role in the oxidation process (Ferrari et al. 1938). 
The oxidation took place along the margin as well as fractured zones of the macerals. At $600^{\circ} \mathrm{C}$, liptinite completely burnt out due to its reactive nature (Ammossov et al. 1957). Oxidation of semifusinite (Fig 2f) is also observed at this temperature. With the increase in temperature at $800^{\circ} \mathrm{C}$, micro foldings were seen in the heataffected semifusinite and fusinite (Fig 2g). The submacerals of inertinite that survived the temperature of 800 and $1000^{\circ} \mathrm{C}$ are mainly sclerotinite and fusinite (Fig $2 \mathrm{~h}$ ). At extreme temperature conditions, weathered vitrinites were also observed (Fig 3a). Weathered vitrinite shows rim structure (Fig 3b) where included minerals altered and deposited at margins. The major minerals such as kaolinite, quartz, pyrite and hematite were found to be present in the feed, some of which get altered with increasing temperature. Quartz and kaolinite were found independently (Fig 3c) and also within the macerals as inclusions. Subhedral to euhedral grains of pyrite occurs in granular as well as framboidal clusters (Fig 3d). Hematite occurs in the maximum heat-treated fractions, which is contributed by the alteration of siderite and pyrite (Fig 3e, f, g). Different sized pores were developed within altered pseudovitrinite (Fig 3h).

[Fig 2 near here]

[Fig 3 near here]

\subsection{X-Ray Diffraction study}

To understand the change in mineral phases, X-ray diffraction analysis was carried out for all the density fractions that are treated with different temperatures. The phases that are initially present in the original sample are subject to change at varying temperature conditions that can be observed from the diffractogram. Figure 4 shows the Xray diffractogram of the feed sample and the four density fractions treated with heat at different temperature conditions.

\section{[Fig 4 near here]}

\section{[Table 2 near here]}

The feed sample contains quartz, kaolinite, siderite, hematite and pyrite (Table 2). The lower density fractions contain quartz and kaolinite, whereas the siderite, hematite and pyrite are concentrated in the highest density fractions. Mullite observed only in the fractions treated with highest temperature condition (i.e., $1000^{\circ} \mathrm{C}$ ). The abundance of hematite in the high-temperature treated fractions are due to the phase transformation of siderite and pyrite. Siderite alters to hematite or maghemite or magnetite above $400^{\circ} \mathrm{C}$ (Pan, Zhu and Banerjee 2000) and pyrite to hematite occurs at or above $800^{\circ} \mathrm{C}$ (Reifenstein et al. 1999). Kaolinite converts to metakaolin at $550^{\circ} \mathrm{C}$ and remains in microcrystalline form till $940^{\circ} \mathrm{C}$ after which it forms mullite (Lee, Kim and Moon 1999). The reactions for the transformation of kaolinite to mullite (I), pyrite to hematite (II) and siderite to hematite (III) can be expressed as follows:-

$$
\text { I. } \begin{aligned}
\mathrm{Al}_{2} \mathrm{O}_{3} \cdot \mathrm{SiO}_{2} \cdot \mathrm{H}_{2} \mathrm{O} \text { (Kaolinite) } & \stackrel{550^{\circ} \mathrm{C} \longrightarrow}{\longrightarrow} \mathrm{Al}_{2} \mathrm{O}_{3} \cdot \mathrm{SiO}_{2}+\mathrm{H}_{2} \mathrm{O} \\
\stackrel{2980^{\circ} \mathrm{C}}{\longrightarrow} \text { Spinel type phase }+\mathrm{SiO}_{2} & \text { Splite) }+\mathrm{SiO}_{2} \\
\stackrel{\geq 1000^{\circ} \mathrm{C}}{\longrightarrow} \mathrm{Al}_{2} \mathrm{O}_{3} \cdot \mathrm{SiO}_{2} \text { (Mullite } &
\end{aligned}
$$




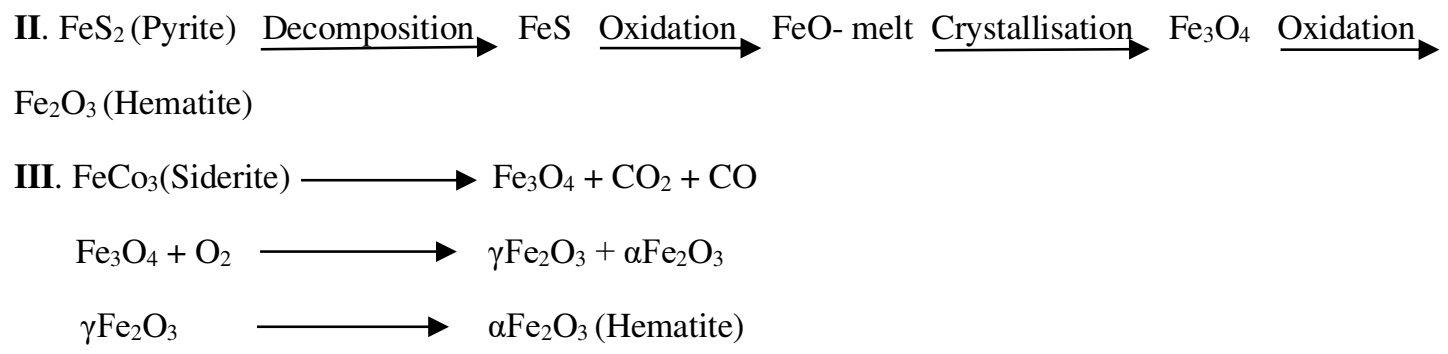

\subsection{Electron Probe Micro Analysis}

In addition to the petrographic study, electron probe microanalysis has also been carried out in certain zones to verify and authenticate the phase transformations. In fig 5, the Fe and S map confirms the presence of subhedral to euhedral grains of pyrite in the feed sample. In fig 6, the conversion of pyrite to hematite is observed. The area showing more concentration of $\mathrm{Fe}$ and $\mathrm{O}$ confirms the presence of hematite and the gradual increase of oxygen concentrations and decrease of sulfur levels confirms the oxidation process of pyrite which is converting into hematite. The other associated phase is clay which is inferred from the elemental distribution of $\mathrm{Al}$ and $\mathrm{Si}$. At the same time, some hematites are also formed from the parent siderite (Fig 7). The grey phase is hematite at the centre in $\mathrm{CP}$ image where the bordering phase is carbonate mineral siderite showing the concentration of Fe, $\mathrm{C}$ and $\mathrm{O}$.

\section{[Fig 5 near here]}

[Fig 6 near here]

\section{[Fig 7 near here]}

\subsection{Fourier-transform Infrared (FTIR) spectroscopic study}

FTIR analysis of the heat-treated samples was carried out in order to ascertain the structural changes in the organic and inorganic constituents present in coal. The FTIR spectra of density fractions at different temperature conditions are represented in Fig 8. The absorption peaks between $3600-3700$ present at 400 and $600^{\circ} \mathrm{C}$ are due to the inherent moisture content (-OH bending) (Rao 1963) that disappears above $600^{\circ} \mathrm{C}$ with the reduction of volatile matter. Peaks between 1600-1950 justify the presence of unsaturated aromatic carbonyl/carboxyl $(\mathrm{C}=\mathrm{O})$ compounds. The presence of unsaturated ketones is interpreted from the peaks near 1610. With the increase in temperature, the area under this curve reduces contributing to more saturated ketonic compounds that can be explained by the peak at nearly 1874 at above $600^{\circ} \mathrm{C}$. The conversion of unsaturated to saturated alkynes $(-\mathrm{C} \equiv \mathrm{C}$ ) can be observed at around 2348 peak position that is completely vanished at a higher temperature.

\section{[Fig 8 near here]}

Most of the peaks falling between 400-1200 are assigned to quartz and alumino-silicates (clay) minerals. The peaks between 900-1100 suggest the occurrence of silicates. The increase in peak depth with increasing temperature concludes the silica enrichment. With an increase in density, the number of peaks for organic matter decreases while inorganic matter increases. The disappearance of liptinite macerals at $>400^{\circ} \mathrm{C}$ can be observed where specific peaks are lost in the spectra. 


\section{Conclusion}

From the above results and discussions, it can be concluded that the telocollinite, submaceral of vitrinite group is readily susceptible to oxidation. Amongst the inertinite group, fusinite, sclerotinite and semifusinite are comparatively more resistant to heat. Liptinite group macerals easily get affected even at a temperature of $400^{\circ} \mathrm{C}$. Presence of quartz and kaolinite in lower specific gravity fractions is due to their included form of existence. With an increase in temperature above $400^{\circ} \mathrm{C}$, siderite phase converted to hematite. Again at or above $800^{\circ} \mathrm{C}$, pyrite oxidized to form hematite and thus leading to enrichment of hematite at high-temperature heat-treated fractions. At an extreme temperature of $1000^{\circ} \mathrm{C}$, kaolinite changed to form mullite. The released silica contributes to the abundance of quartz at higher heat-treated fractions in the process of mullite formation from kaolinite. From the FTIR analysis, it can be said that with the increase in temperature, unsaturated bonds are converted into a more saturated and stable form, thereby reducing carbon content with increase in silicates.

\section{Declarations}

- Availability of data and materials: All datasets were available in the main paper.

- Competing interests: The authors hereby declare that we have no competing interest.

- Funding: The first author (R. Bhatta) is indebted to the University Grants Commission for the financial support in terms of research fellowship.

- Authors' contributions: The first author is the research scholar carried all the investigations including field visit and preparation of manuscript. The second and corresponding author is the supervisor who dealt with petrographic investigation of the samples. The third author involved in field work and guiding the preparation of manuscript.

- Acknowledgements: The authors are thankful to the Director, CSIR-IMMT, for permitting to publish this paper. We are also thankful to Dr. S. I. Angadi, Dr. B. K. Nayak and Dr. D. Satpathy of Mineral Processing Department for extending their support in the analytical work.

\section{References}

Acma HH, Yaman S, Kucukbayrak S, Okutan H (2006) Investigation of the combustion characteristics of zonguldak bituminous coal using DTA and DTG. Energy Sources, Part A 28: 135-147. doi:10.1080/009083190889799.

Ammossov IL, Eremin IV, Sukhenko SF, and Oshurkova LS (1957) Calculation of coking charges on the basis of petrographic characteristics of coals. Koks Khim 12:9-12.

Balachandran, M (2014) Role of Infrared Spectroscopy in Coal Analysis-An Investigation. American Journal of Analytical Chemistry 5:367-372.

Bhowmick T, Nayak B, Varma AK (2017) Chemical and mineralogical composition of Kathara Coal, East Bokaro Coalfield, India. Fuel 208: 91-100. doi:10.1016/j.fuel.2017.07.013.

Blanc P, Valisolalao J, Albrecht P, Kohut JP, Muller JF, Duchene JM (1991) Comparative geochemical study of three maceral groups from a high-volatile bituminous coal. Energy Fuels 5: 875-884. 
Burchill P, Richards DG, Warrington SB (1990) A study of the reactions of coals and coal minerals under combustion-related conditions by thermal analysis-mass spectrometry and other techniques. Fuel 69: 950-956.

Bureau of Indian Standard (BIS) (First revision of IS: 9127) (2002) Methods for the petrographic analysis of bituminous coal and anthracite (Part 2), Method of preparing coal samples. New Delhi: Bureau of Indian Standard.

Cheng J, Zhang Y, Wang T, Norris P, Chen WY, Pan WP (2017) Thermogravimetric-Fourier Transform Infrared Spectroscopy-Gas Chromatography/Mass Spectrometry Study of Volatile Organic Compounds from Coal Pyrolysis. Energy and Fuels 31: 7042-7051.

Coal India Limited (1993) Coal atlas of India. Ranchi: Central Mine Planning \& Design Institute Limited.

Dyk JCV, Benson SA, Laumb ML, Waanders B (2009) Coal and coal ash characteristics to understand mineral transformations and slag formation. Fuel 88: 1057-1063.

Dyrkacz GR, Horwitz EP (1982) Separation of coal macerals. Fuel 61: 3-12.

Ferrari, B (1938) Die Entstehung von Grubenbründen nach Untersuchungen auf kohlen petrographischer Grundlage (Coal-petrographic Investigations into the Origin of Mine Fires): Glückauf 74: 765-774.

Giroux L, Charland JP, MacPhee JA (2006) Application of thermogravimetric Fourier transform infrared spectroscopy (TG-FTIR) to the analysis of oxygen functional groups in coal. Energy \& Fuels 20: 1988-1996.

Holuszko M, Kumar A, Kuppusamy VK and Engwayu J (2018) Investigation of the effect of particle size petrographic composition, and rank on the flotation of Western Canadian coals. International Journal of Coal Preparation and Utilization. doi:10.1080/19392699.2018.1490277.

Kinghorn RRF, Rahman M (1980) The density separation of different maceral groups of organic matter dispersed in sedimentary rocks. Journal of Petroleum Geology 2(4): 449-454.

Koenig JL (1975) Application of Fourier Transform Infrared Spectroscopy to Chemical Systems. Applied Spectroscopy 29: 293-308.

Kruszewska K (1989) The use of reflectance to determine maceral composition and the reactive-inert ratio of coal components. Fuel 68: 753-757.

Lee S, Kim YJ, Moon HS (1999) Phase Transformation Sequence from Kaolinite to Mullite Investigated by an Energy-Filtering Transmission Electron Microscope. J. Am. Ceram. Soc. 82(10): 2841-2848.

Misra SK and Mohanty JK (2005) Importance of Petrographic Study of Non-Coking Coals from Talcher Coal Field, Orissa in Coal Utilisation. Journal Geological Society of India 66: 475-485.

Morga R (2010) Chemical structure of semifusinite and fusinite of steam and coking coal from the Upper Silesian Coal Basin (Poland) and its changes during heating as inferred from micro- FTIR analysis. Int J Coal Geol 84: 115. doi:10.1016/j.coal.2010.07.003.

Nag D, Das B and Saxena VK (2016) Enhancement of Coking Properties of Coal by Differential Screening. International Journal of Coal Preparation and Utilization 36: 1-9. doi: 10.1080/19392699.2015.1046597.

Nandi BN, Brown TD, and Lee GK (1977) Inert coal macerals in combustion, Fuel 56: 125-130. 
Nankervis JC, Furlong RB (1980) Phase changes in mineral matter of North Dakota lignites caused by heating to $1200^{\circ} \mathrm{C}$. Fuel 59: 425-430.

Nayak B (2013) Mineral Matter and the Nature of Pyrite in Some High-sulfur Tertiary Coals of Meghalaya, Northeast India. Journal Geological Society of India 81: 203-214.

Orrego JA, Hernandez RC, Mejia-Ospino E (2010) Structural study of colombian coal by fourier transform infrared spectroscopy coupled to attenuated total reflectance (FTIR-ATR). Revista Mexicana De Fi'Sica 56(3): 251-254.

Ozbas KE, Kok MV (2003) Effect of Heating Rate on Thermal Properties and Kinetics of Raw and Cleaned Coal Samples. Energy Sources 25: 33-42. doi:10.1080/00908310290142091.

Pan YX, Zhu RX, Banerjee SK (2000) Rock magnetic properties related to thermal treatment of siderite: Behavior and interpretation. J. Geophys. Res 105: 783-794. doi:10.1029/2002GL016021.

Querol X, Turiel JLF, Soler L (1994) The behaviour of mineral matter during combustion of Spanish subbituminous and brown coals. Mineralogical Magazine 58: 119-133.

Raask E (1985) Mineral Impurities in Coal Combustion: Behavior, Problems, and Remedial Measures. Hemisphere Publishing Corporation 484.

Sun Q, Li W, Chen H, Li B (2003) The variation of structural characteristics of macerals during pyrolysis. Fuel 82: 669-676.

Rao CNR (1963) Chemical Application of Infrared Spectroscopy. Academic press.

Reifenstein AP, Kahraman H, Coin CDA, Calos NJ, Miller G, Uwins P (1999) Behaviour of selected minerals in an improved ash fusion test: quartz, potassium feldspar, sodium feldspar, kaolinite, illite, calcite, dolomite, siderite, pyrite and apatite. Fuel 78: 1449-1461.

Sahoo M, Bhowmick T, Mishra V, Pal S, Sharma M and Chakravarty S (2019) Significance of coal quality on thermoplastic properties: a case study. International Journal of Coal Preparation and Utilization. doi:10.1080/19392699.2019.1678470.

Saikia BK, Boruah RK, Gogoi PK (2007) XRD and FT-IR investigations of sub-bituminous Assam coals. Bull. Mater. Sci. 30:421-426.

Singh AK (2016) Petrographic and Geochemical Characterization of Coal from Talcher Coalfield, Mahanadi Basin, India. Journal Geological Society of India 87: 525-534.

Thomas L (2013) Coal geology. 2nd ed. Wiley-Blackwell, John Wiley \& Sons Ltd.

Singh MP, Singh PK, Singh AK (2003) Petrography and Depositional Environments of the Permian Coal Deposits of Deoghar Basin, Bihar. Journal Geological Society of India 61: 419-438.

Solomon PR and Carangelo RM (1988) FTIR analysis of coal. Fuel 67: 949-959. 
Stach E, Mackowsky M-Th, Teichmuller M, Taylor GH, Chandra D, and Teichmuller R (1982) Stach's textbook of coal petrology. 3rd ed. Berlin: Gebrüder Borntraeger.

Vassilev SV, Eskenazy GM, Tarassov MP, Bulgarian VI (1995) Mineralogy and geochemistry of a vitrain lens with unique trace element content from the Vulche Pole coal deposit, Bulgaria. Geologica Balcanica 25: 111-124.

Vassileva CG, Vassilev SV (2002) General observations on the phase-mineral transformations in inorganic matter of some Bulgarian coals during heating, comptes rendus del'academie bulgare des sciences 55(7): 47-50.

Vassileva CG, Vassilev SV (2005) Behaviour of inorganic matter during heating of Bulgarian coals, 1. Lignites. Fuel Process Technol 86: 1297- 1333. doi:10.1016/j.fuproc.2005.01.024.

Vassileva CG, Vassilev SV (2006) Behaviour of inorganic matter during heating of Bulgarian coals of Subbituminous and bituminous coals. Fuel Process Technol 87: 1095-1116.

White A, Davies MR, Jones S (1989) Reactivity and characterization of coal maceral concentrates. Fuel 68: 511519.

Xie KC, Zhang YF, Li CZ, Ling DQ (1991) Pyrolysis characteristics of macerals separated from a single coal and their artificial mixture. Fuel 70: 474-479.

Xuguang S (2005) The investigation of chemical structure of coal macerals via

transmitted-light FT-IR microspectroscopy. Spectrochimica Acta Part A 62: 557-564. doi:10.1016/j.saa.2005.01.020.

Yao S, Zhang K, Jiao K, Hu W (2011) Evolution of coal structures: FTIR analyses of experimental simulations and naturally matured coals in the Ordos Basin, China. Energy Exploration \& Exploitation 29: 1-19. doi:10.4236/ajac.2014.56044.

Yavorski IA, Alaev GP, Pugach LI, Talankin LP (1968) Information of the petrographic composition of coals on the efficiency of a pulverised fuel fired boiler furnace. Teploenergetica 15: 69-72.

Zhang L, Hower JC, Liu W, Men D (2016) Maceral liberation and distribution of bituminous coal for predicting maceral separation performance. International Journal of Coal Preparation and Utilization. doi:10.1080/19392699.2016.1160898. 
Figures

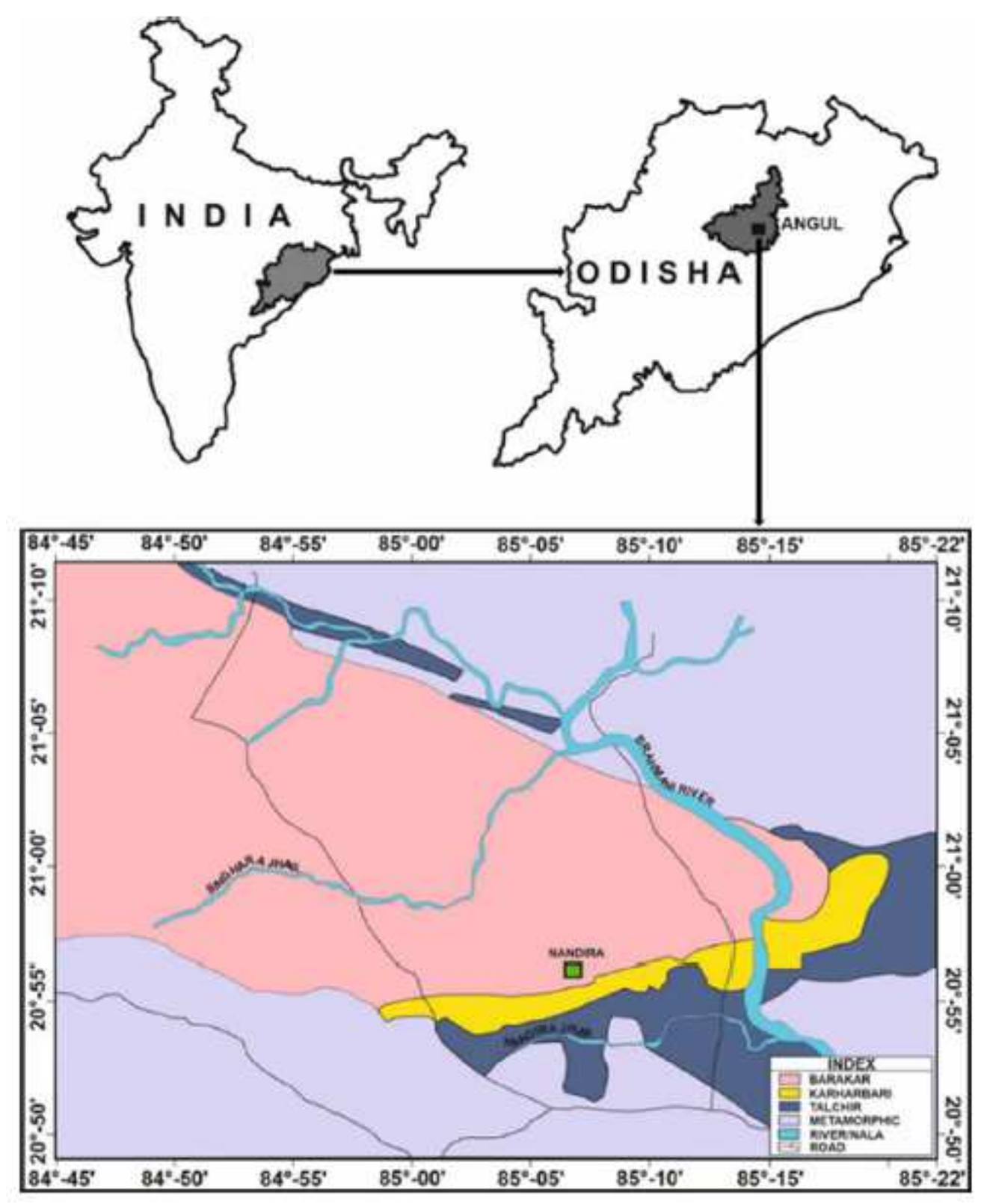

Figure 1

Geological map of Talcher coalfield showing the location of Nandira colliery (Source: Coal India Limited, Kolkata) (Coal India Limited 1993) 

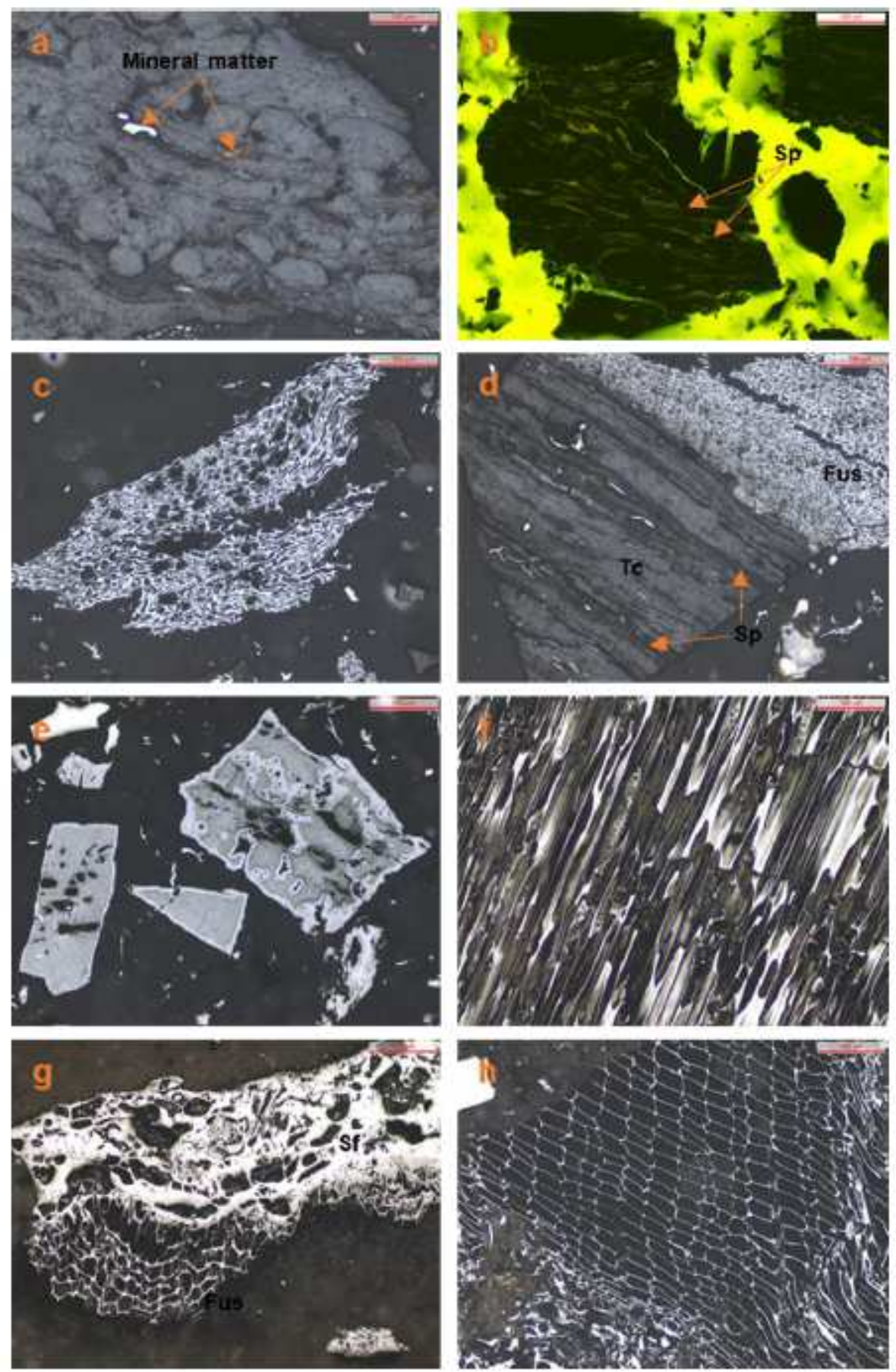

Figure 2

Photomicrographs of macerals present in feed sample (a-d) and heat-treated samples (e-h). a. Corpocollinite with mineral inclusions, b. Sporinite (light orange colour) in fluorescence light, c. Bogen structure of fusinite, $d$. Trimaceral consisting of telocollinite, sporinite and fusinite, e. Oxidized rim around the margin of telocollinite, f. Oriented oxidized semifusinite, g. Folding in semifusinite and fusinite, $h$. Heat unaffected fusinite. (Sp-Sporinite, Tc- Telocollinite, Fus- Fusinite, Sf-Semifusinite) 

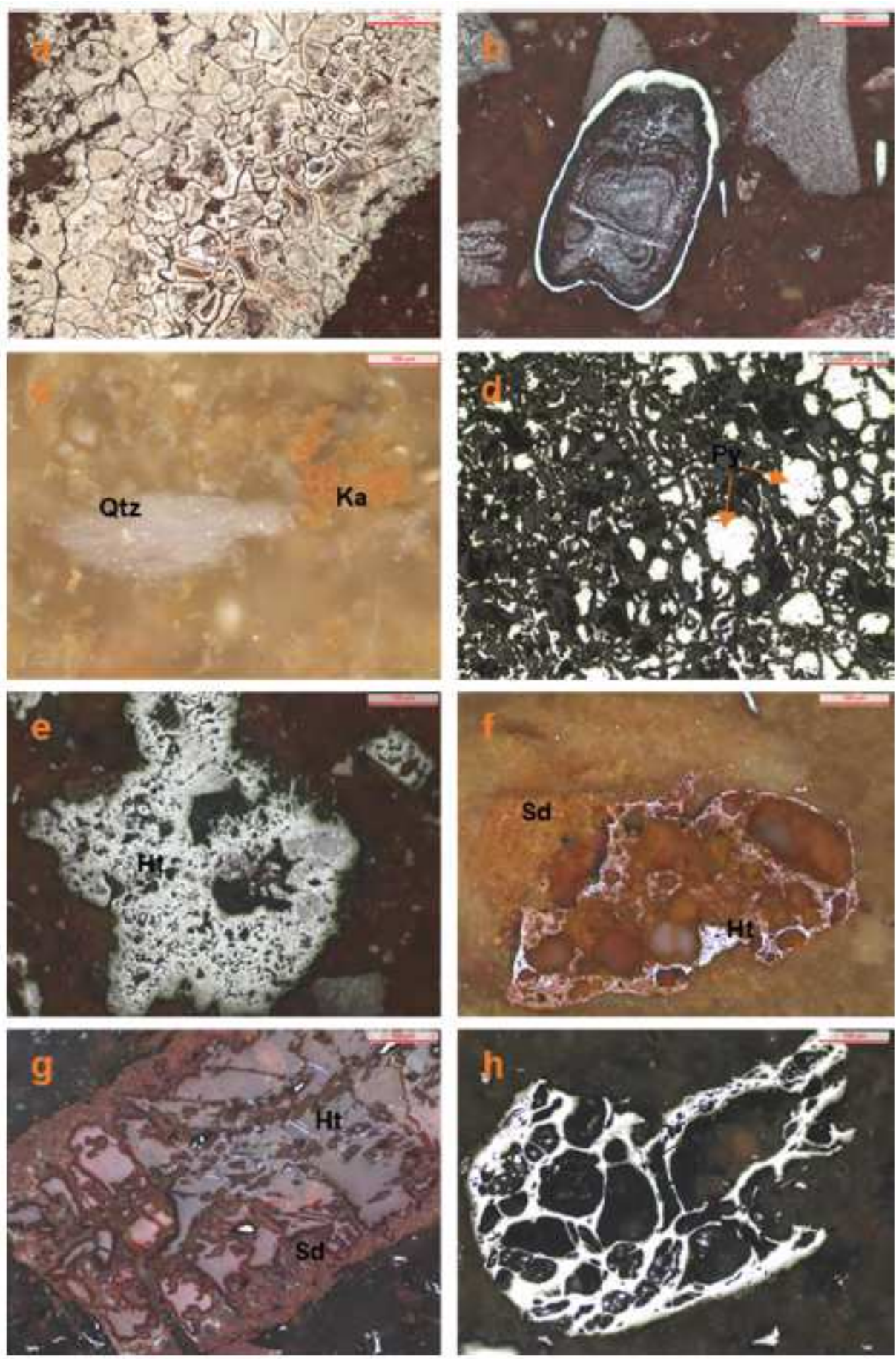

Figure 3

Photomicrographs of heat-treated minerals (a-h). a. Weathered vitrinite showing cracks, b. Heat affected telocollinite showing rim, c. Independent grain of quartz and kaolinite, d. Cluster of pyrites within maceral, e. Large patch of Hematite f. Siderite in association with hematite, g. Specs of hematite alongwith siderite, h. Altered Pseudovitrinite with pores. (Qtz- Quartz, Ka- Kaolinite, Py- Pyrite, Ht- Hematite, SdSiderite) 

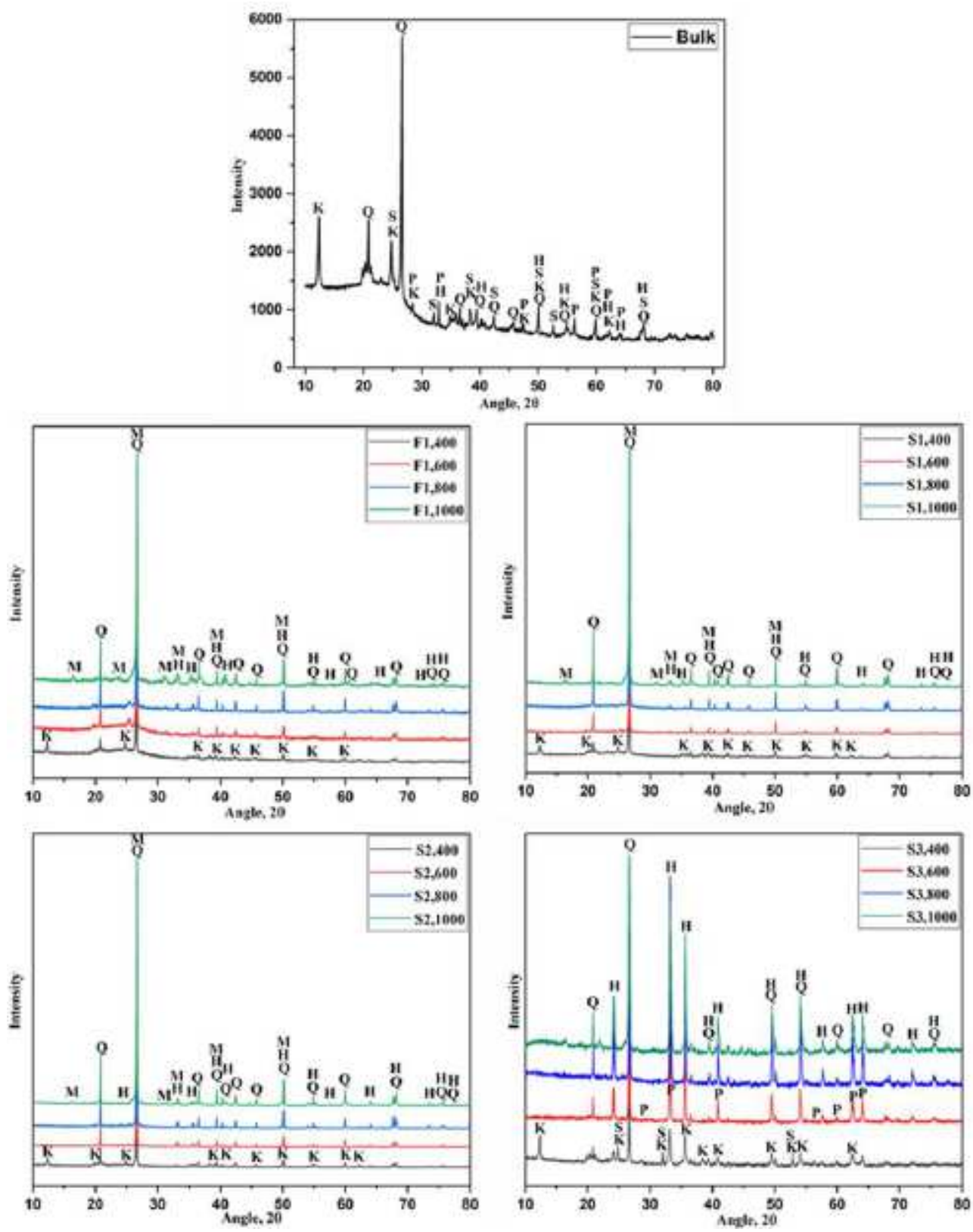

Figure 4

X-ray diffractograms of feed coal sample and the density fractions treated at different temperatue conditions $(\mathrm{Q}=$ Quartz, $\mathrm{K}=$ Kaolinite, $\mathrm{H}=$ Hematite, $\mathrm{S}=$ Siderite, $\mathrm{P}=$ Pyrite, $\mathrm{M}=$ Mullite $)$ 

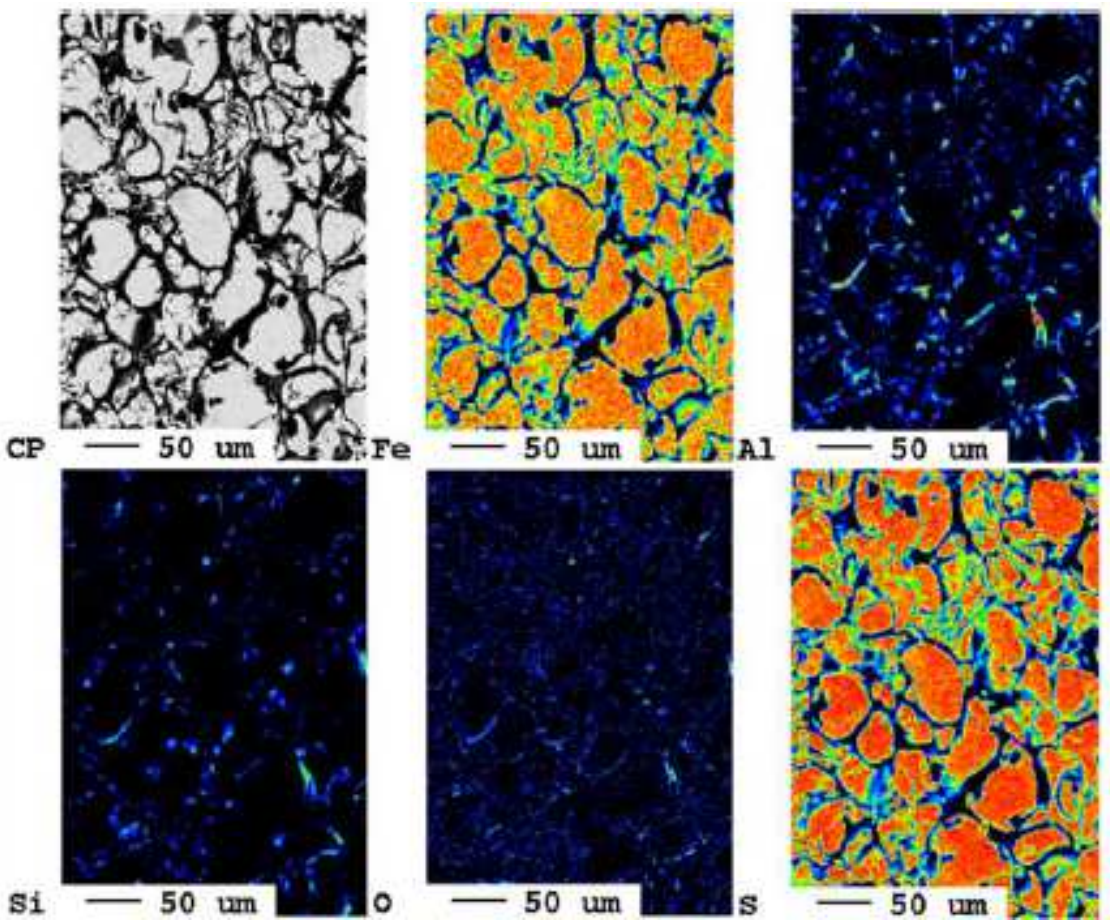

Figure 5

Back Scattering Electron image of pyrite in the feed sample (CP) and the elemental maps for $\mathrm{Fe}, \mathrm{Al}, \mathrm{Si}, \mathrm{O}$ and S. The concentration of Fe and S confirms the composition of pyrite

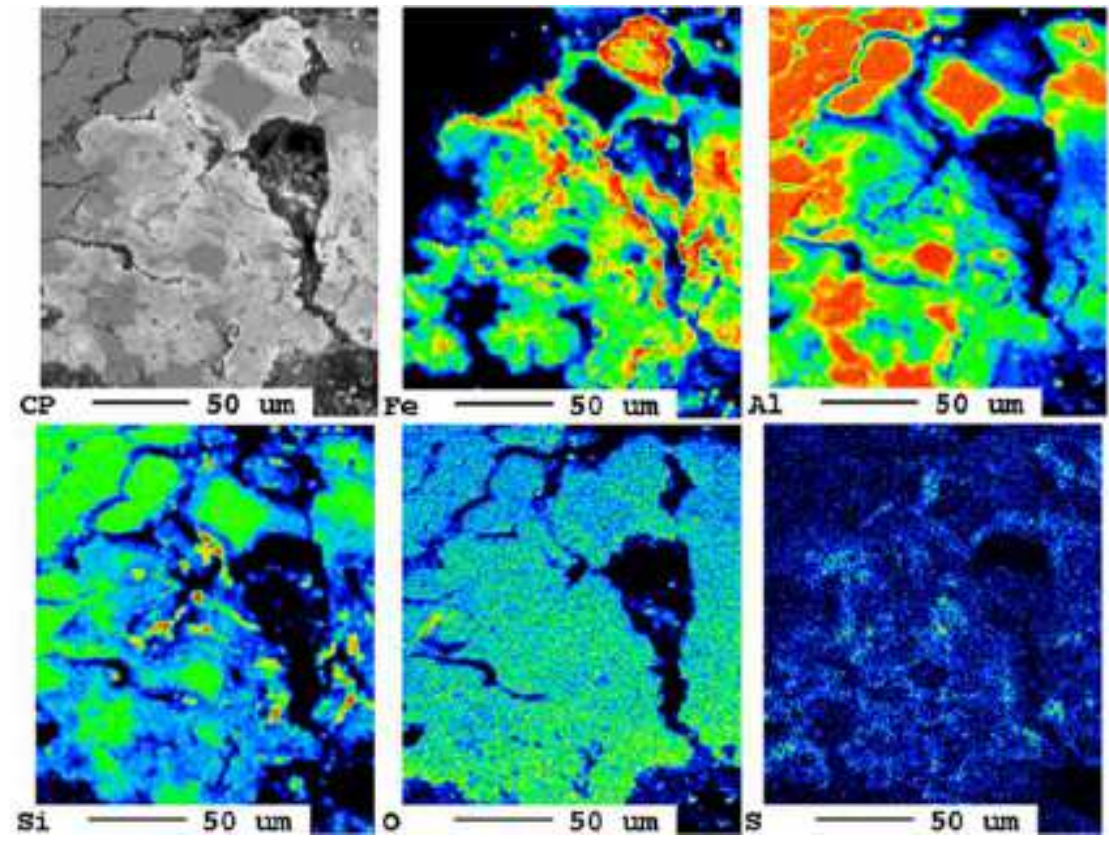

Figure 6

Back Scattering Electron image of partially oxidized pyrite in a heat-treated sample (CP) and the elemental maps for $\mathrm{Fe}, \mathrm{Al}, \mathrm{Si}, \mathrm{O}$ and $\mathrm{S}$ showing the conversion of pyrite to hematite 

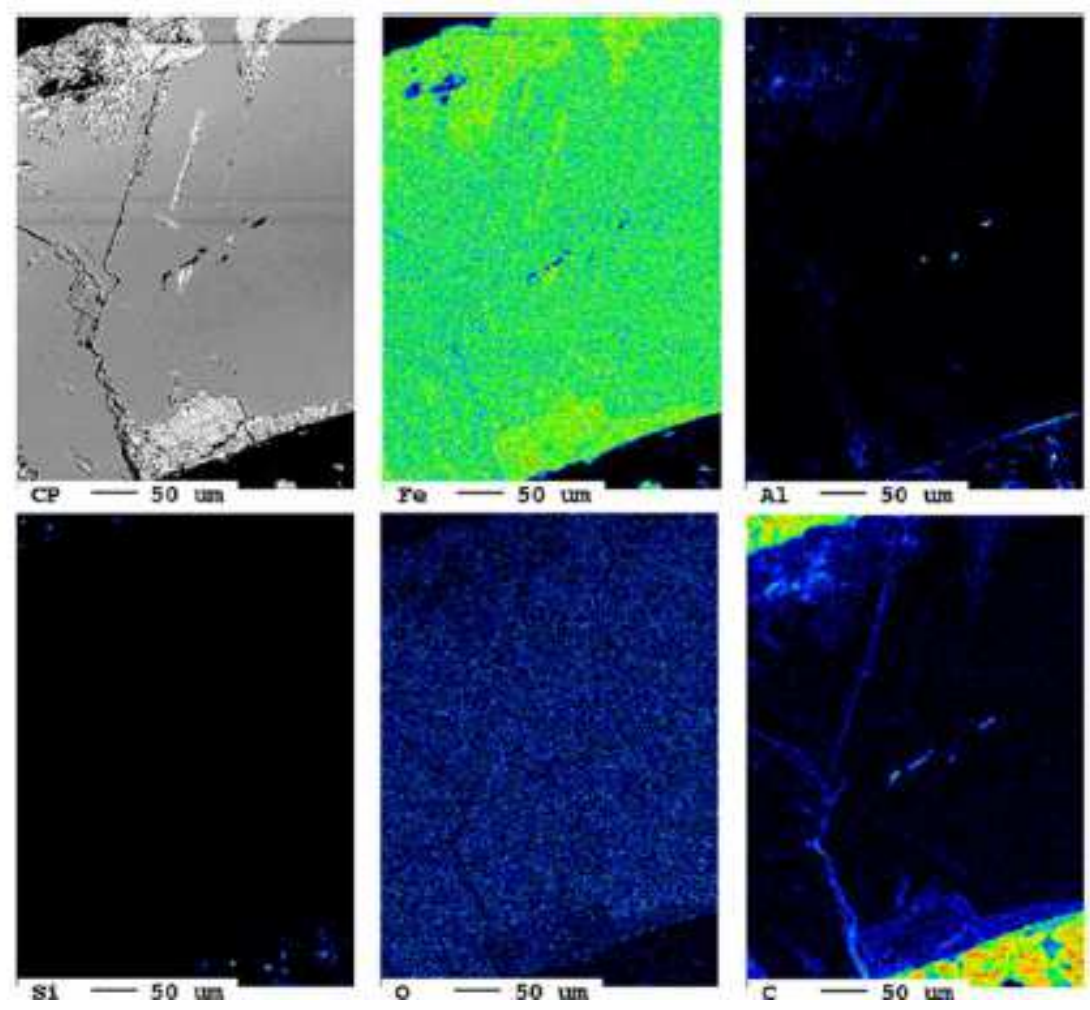

\section{Figure 7}

Back Scattering Electron image of partially oxidized siderite (CP) in a heat-treated sample and elemental maps for $\mathrm{Fe}, \mathrm{Al}, \mathrm{Si}, \mathrm{O}$ and $\mathrm{S}$ showing the conversion of siderite to hematite
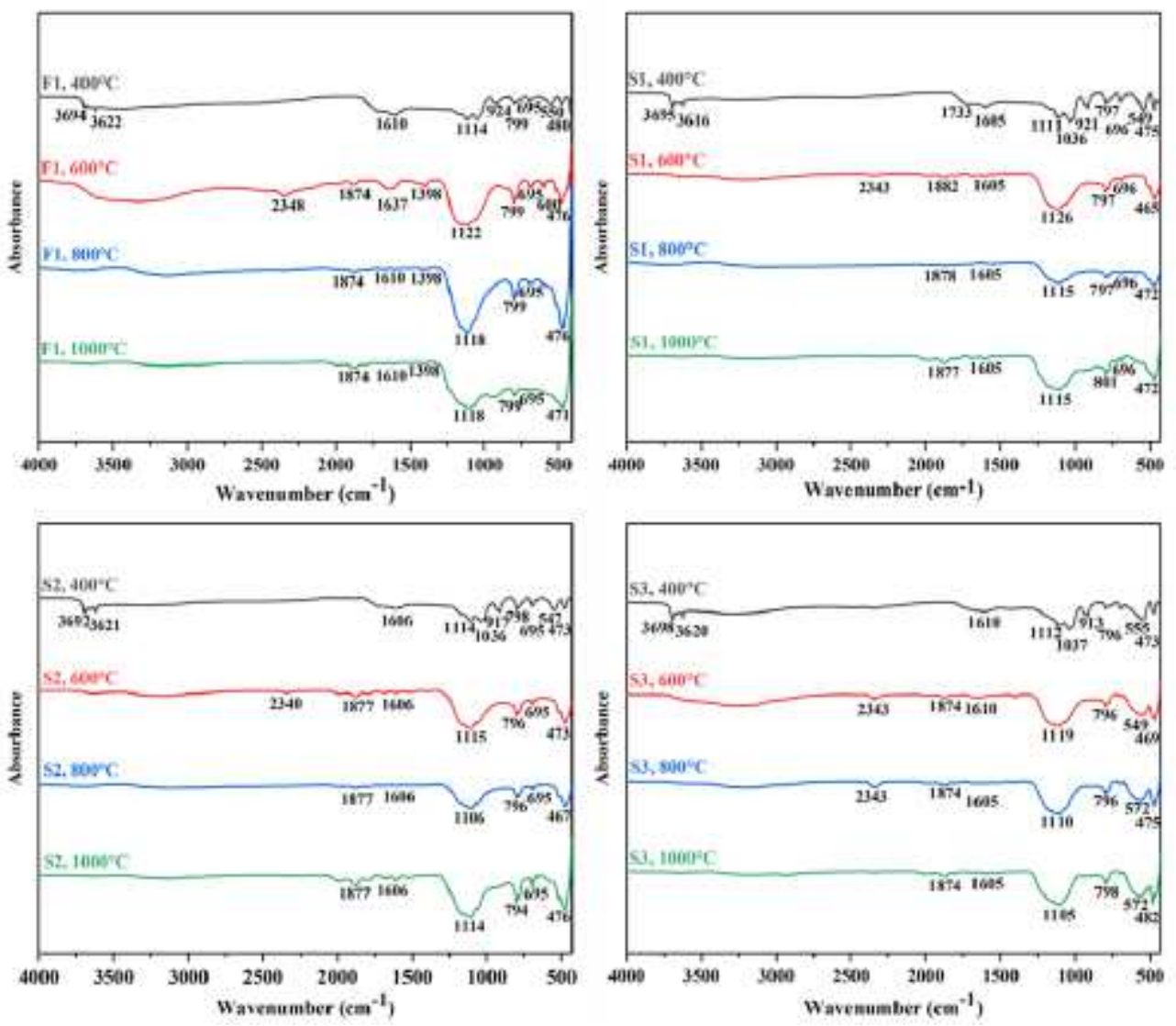
Figure 8

FTIR spectra of density separated coal samples at different temperature conditions 